\title{
VERSITA
}

Ekológia (Bratislava)

Vol. 32, No. 4, p. 369-375, 2013

doi:10.2478/eko-2013-0034

\section{APPLYING LANDSCAPE ECOLOGICAL PRINCIPLES IN SUSTAINABLE FOREST MANAGEMENT OF THE FLOODPLAIN FOREST IN THE TEMPERATE ZONE OF EUROPE}

\author{
IVO MACHAR
}

University Palacky, Žižkovo nám.5, 77140 Olomouc, Czech Republic; e-mail: ivo.machar@upol.cz

\begin{abstract}
Machar I.: Applying landscape ecological principles in sustainable forest management of the floodplain forest in the temperate zone of Europe. Ekológia (Bratislava), Vol. 32, No. 4, p. 369-375, 2013.

European floodplain forests of the temperate climatic zone are an example of an ecosystem in the cultural landscape characterized by an exceptionally high biodiversity. In this usually heavy deforested landscape of the Central and South European river floodplains, which are subjected to intensive agricultural use, the preserved ecosystems of floodplain forests represent important refuges for biotic biodiversity and are invaluable for the ecological landscape stability of the entire floodplain and the wider river basin. Unlike other Central European communities, whereby constant ecological conditions of habitats tend to be preserved even upon changes in ecosystem, the floodplain forests are characterized by a long-term continuous development of ecotopes, conditioning the complex interconnected succession series of ecosystem. The ecological floodplain phenomenon is created by fluvial landscape processes and the conservation of the natural development dynamics of the said fluvial landscape processes is essential for its protection.

The landscape structure of floodplain forests is significantly affected by forest management measures, including regeneration methods, silvicultural measures and felling. Floodplain forest management radically affects the biodiversity of the given ecosystems which are listed among habitats of European concern in the Natura 2000 network. Since understanding of the biological nature of forest ecosystems is essential for landscape and ecological planning and sustainable forest management, it is imperative to study ecological processes taking place in the various floodplain forest biotopes in order to be able to define the principles of their management.

This article aims to contribute to the process of formulating principles of biodiversity protection and the management strategies for floodplain forest ecosystems, while applying some theories and methods of landscape ecology. The Results section of the article comes in the form of case studies for each topic and draws on original data which were published in the scientific journals or presented at scientific conferences (see References). Some of the presented case studies focus on the Protected Landscape Area Litovelské Pomoraví.
\end{abstract}

Key words: biodiversity, ecosystem management, floodplain forest, sustainable forest management.

\section{Introduction}

Sustainable forest management combines conservation and management of forest ecosystems in the landscape (Starr, 2005). Sustainable forest management stems from the so-called principle of forest sustainability (Míchal et al., 1992), which identifies the term 'forest' with the term 'forest ecosystem' and considers the timber obtained by forest exploitation as con- 
stantly renewable natural resource. Sustainable forest management is based on the ecosystem approach under the Convention on Biological Diversity (Roth, Plesník, 2004) and can be basically implemented through two main types of forest management:

- $\quad$ Species-based management (Mace, Baillie, 2007). This type of management is based on the concept of conservation of interest species - focal species - which include, for example, umbrella species, keystones species, rare species and flagship species.

- Ecosystem management (Koontz, Bodine, 2008). This type of management considers the whole ecosystem in a certain defined form as 'object of protection'; For example, it can be a richly structured and a close-to-nature floodplain forest ecosystem (Oszlányi, 2000). The whole system of economic measures in stands and the management is then subordinated to continuous preservation of this ecosystem.

Sustainable forest management considers a man in the landscape as a key biological species (Angelstam, 1997).

Floodplain forests of the European temperate zone are described in the monograph by Klimo et al. (2008). Floodplain forest ecosystems are characterized by a number of definitions. Vašíček (1985) defines floodplain forests as 'specific forest geobiocenoses the species diversity of which depends on the ecotope formed by quaternary riverine alluvium, floods and high groundwater level, usually in the first half of the growing season'.

The biodiversity of floodplain forests is significantly influenced by the hierarchical level of $\beta$-diversity (beta-diversity), i.e. by the changes in biodiversity depending on the changes in environmental gradients (in this case, these are changes in micro-relief and meso-relief of the floodplain that are dependent on the distance from the water flow, changes in the range of floods, etc.). Floodplain forests are ecosystems with extremely high primary and secondary organic production. At present, it is clear that the traditional emphasis on forest-economic producing function of floodplain forests (Mezera, 1956) is shifting on the ecosystem functions of floodplain forests in the landscape (Klimo, Hager, 2001), such as function of biodiversity centres, function of flood protection and role in the accumulation of phosphorus, nitrogen and carbon, etc.

It is important for sustainable management of floodplain forest ecosystems irrespective of whether the floodplain water regime and sedimentation process of alluvial loams are affected or unaffected by hydraulic engineering works in the landscape. If the floodplain landscape is strongly influenced by the system of water-management alterations (e.g. including river regulations and construction of flood-control reservoirs), the floodplain forest soil merges into the evaporation regime and the floodplain forest dries up; this finally results in the loss of biodiversity with regard to the wetland and wet biotope types. A solution within the management activities are then the so-called water regime revitalizations (Prach et al., 1996). An example can be the area of riparian forests at the confluence of the Morava River and Thaya River in the Lower Morava Biosphere Reserve.

Conversely, when the floodplain is not affected by water-engineering modifications, the landscape retains its basic ecosystem functions. In such case, the high beta-diversity of the floodplain ecosystems is determined by the fluvial dynamics of the river flow. The variegated mosaic of different biotope types in the floodplain, from biotopes of naturally meandering river over biotopes of riverine islands, side river arms and wetlands, across different types of 
softwood floodplain forest to hardwood floodplain forest types, is called the 'dynamic fluvial succession series' (Buček, Lacina, 1994). This mosaic of floodplain biotopes, varying in time and space due to river dynamics, creates the so-called environmental floodplain phenomenon (Machar, 2001).

It can be concluded from the above that successful protection of biodiversity in dynamic floodplain forest ecosystems does not necessarily require territorial (passive, preservative) protection in the form of various categories of protected areas or the mere provision of connectivity between the ecosystems in the landscape through ecological networks. The key to continuous preservation of biodiversity in the floodplain forest is maintaining the conditions for the functioning of ecological floodplain phenomenon (Oszlányi, 1999). This means that the basic principle of maintaining the floodplain forest biodiversity is the protection and undisturbed functioning of the dynamics of fluvial erosion and accumulation processes in the landscape. Floodplain forest protection is, thus, clearly based on the ecosystem approach which places emphasis on creating the conditions for the functioning of the floodplain forest ecosystem services (Malanson, 1993).

\section{Case studies from the Czech Republic}

The need for sustainable management of floodplain forest ecosystems arises from the fundamental landscape-ecological functions of the alluvial landscape. A practical example is the application of landscape ecology in solving the complex protection of ecological alluvial phenomenon in the Protected Landscape Area Litovelské Pomoraví in the Czech Republic (Machar, Pechanec, 2011).

The aim of this study is to apply geomorphological typology of river systems (Angradi et al., 2004) and the theory of dynamic fluvial succession series of floodplain biotopes (Buček, Lacina, 1994) to define an optimal delimitation of the core zone in the protected area, so that this core zone accommodates the ecologically most valuable biotopes of floodplain forests, forming a comprehensive ecological alluvial phenomenon. The method of gap analysis (Olson, Dinerstein, 1998) applied in the environment of geographic information system Arc Info helped in defining a territory that includes, at the same time, river meander belt and all types of floodplain forest biotopes, whereas each type of biotope in the core area contains at least one segment reaching the defined minimum acreage of forest ecosystem capable of spontaneous development according to Vacek (2003).

One example of the application of landscape-ecological floodplain concepts in alluvial forest biodiversity conservation is the set of studies (Machar, 2010) dealing with the assessment of impacts on floodplain forests in the Czech Republic associated with the project of Danube-Oder-Elbe (DOL) canal and using three concepts of landscape ecology: (1) biogeographical differentiation of the landscape under geobiocoenological concept (Buček, Lacina, 2006), (2) landscape-ecological applications of the concept of focal species (Lambeck, 1987) and (3) the concept of valuation of biotopes in the landscape (Seják, Dejmal, 2003). These landscape-ecological concepts were applied in quantifying the extent of anthropogenic impacts on floodplain forest ecosystems due to the assessed 
project of DOL canal (Buček, Machar, 2012). Practical applications in evaluations within EIA (ecological impact assessment) process are provided by the concept of assessing ecosystem services (Seják, Pokorný, 2008).

Application of the concept of ecological networks in restoring the river landscape ecosystem functions of Morava River near town Olomouc shows study Machar (2012a)

The key principle regarding the solution to river landscape restoration within the study area is the proposal for conversion of arable land along the Morava River to 'river landscape' consisting of a mosaic of floodplain biotopes. The concept of the proposal for restoring the river landscape is based on the creation of a supra-regional bio corridor of the territorial system of ecological stability along the Morava River in the form of dike floodplain whose axis is the revitalized river. The bio corridor territory will, thus, allow free flood extent.

In order to determine the project characteristics of the Morava River bed needed for specifying the target state of bed-forming processes under the current conditions of the site in question, we performed a geomorphological analysis in compliance with the methodology of Vlček and Šindlar (2002). Subsequently, the bed width at the bed-forming flow, $B_{k}$, and the bed mean depth at the bed-forming flow, $\mathrm{HQ}_{\mathrm{k}}$, were designed based on the analogies derived according to the close-to-nature reference stretches in Litovelské Pomoraví. Upon graphic solution using the multiple regression analysis in the basic type of display matrices for the condition with induced change in water flow regime and according to the river course water content, we determined the following parameters: bed route sinuosity, width and sinuosity of the first alluvial zone and meander belt, the meander length and the relative frequency of ford alternations along the longitudinal bed profile. The strip of land to restore the riverine landscape of the Morava River was then determined from the width of the meander belt and its extension up to the edge of the first alluvial zone (if identifiable in the terrain) or up to the natural as well as artificial obstacles limiting the possibility of flood extent in the riverine landscape.

Creation of the bio corridor is part of the adaptation measures in the floodplain landscape in the context of global changes. The bio corridor (floodplain forests and meadows) actually creates a natural flood retention area (polder) that protects the surrounding settlements in the floodplain against the increasing frequency of floods that can be expected in relation to the predicted effects of global change in the landscape (Pretel, 2009).

Application of island biogeography in conservation and management of the floodplain forest based on results from research of the structure and diversity of bird communities demonstrate next studies

Long-term protection of richly structured floodplain forest in the statute of strict (non-intervention) reservation, representing 20 years of spontaneous development of the floodplain forest ecosystem, leads to statistically significant increase in the density of bird assemblage (Machar, 2011).The long-term protection of the old and richly structured floodplain forest ecosystem was reflected in the structure of nesting ornitocoenosis by statistically significant 
increase in density, particularly in the guild of birds nesting in tree cavities and in the shrub layer. This apparently arises from the protection of forest ecosystem in the form of natural reserve; thanks to the absence of forestry interventions, it is possible to view the development of natural regeneration of woody plants and shrub layer as well as gradual increase in the offer of nesting cavities in older and dying trees not removed from the undergrowth. With regard to the protection of bird species significant for the European Natura 2000 network, the finding of long-term abundance stability of species Ficedula albicollis and Dendrocopos medius is important. Species composition of the nesting ornitocoenosis has not fundamentally changed and was fairly stable in the time span of 20 years.

Fragmentation of the continuous complex of floodplain forest ecosystem through logging (accompanied by the emergence of clearings) leads to increase in the species diversity of nesting bird assemblage (within the study locality, the diversity increased by seven species after fragmentation). However, some nesting species typical for the inner forest environment of old floodplain forest have disappeared (Dryocopus martius, Dendrocopos medius). From the statistical point of view, the overall average density of the assemblage after forest fragmentation has decreased only insignificantly (Machar, 2012b).

Continuous complexes of old floodplain forest stands in the alluvial landscape can be perceived as islands of biodiversity in intensively cultivated agricultural landscape. Our ornithological studies have shown that in these 'island' ecosystems, through the bird assemblage structure and diversity, it is possible to observe environmental effects known from the theory of island biogeography. Results from such applied studies may significantly contribute to the formulation of strategies for sustainable management of floodplain forest ecosystems.

In another study conducted in Litovelské Pomoraví (Šindlar et al., 2010), we examined the so-called wood debris, i.e. dead wood in a naturally meandering watercourse. Wood debris is one of the key factors influencing the fluvial dynamics of naturally meandering river. Therefore, wood debris also significantly affects the formation of a mosaic of different types of floodplain forests, especially the so-called softwood floodplain forest on river islands and gravel-sand alluviums on river banks. Based on the categorization of the river into stretches according to the accumulation of various types and quantities of wood debris, we designed the principles of wood debris management in the protected area.

\section{Conclusion}

1. Detailed examples of using the landscape ecology in conservation and management of the floodplain forest in the temperate zone of Europe can be found in a number of specialized monographs (e.g. Darby, Sear, 2008; Eiseltová, 1995; Trémoliéres, Schnitzler, 2007). In this paper, only some selected examples from the author's own experience were briefly presented. In a particular case, the practical application of ecological theories and principles in the management of floodplain forest can be complicated by two factors: Various biological species of interest may have substantially different (and sometimes conflicting) demands on the floodplain forest biotope. A typical example is the 'conflict of interest' between the so-called interior species (species of the internal environment) and edge species. For example, wood warbler (Phylloscopus sibilatrix) and black stork 
(Ciconia nigra) are typical interior species requiring continuously involved, shady and extensive 'dark' floodplain forest with full stocking and dense crown canopy. Edge species such as the clouded Apollo butterfly (Parnassius mnemosyne) and large longhorn beetle (Cerambyx cerdo) live in the same type of floodplain forest, requiring open structure of the floodplain forest (preferably the so-called savannah or grazing forest) with solitary old oaks standing alone so that their bark is exposed to direct sunrays.

2. In one particular area of the floodplain forest, a number of different and by-law-defined interests of nature conservation can overlap and sometimes even stand against each other.

The basis for practical implementation of sustainable forest management of floodplain forests in protected areas pursuant to the landscape-ecological theories should be the definition of the protection subject matter. With regard to the clearly defined subject matter of protection, it is also necessary to specify its objective (purpose). For example, the protection subject matter can be a specific type of floodplain forest ecosystem. The protection objective then may be the preservation of such ecosystem in its natural state, which reflects the persistent ecological conditions of the locality. This protection objective is subsequently achieved through ecosystem management clarified by the so-called management plan.

An example of the realized concept of sustainable floodplain forest management according to the above-mentioned principles can be the management of floodplain forests in the Protected Landscape Area Litovelské Pomoraví implemented differentially pursuant to the PLA territory division into structured nature conservation zones (Machar, 2008).

\section{References}

Angelstam, P. (1997). Landscape analysis as a tool for the scientific management of biodiversity. Boreal ecosystems and landscapes - structures, functions and conservation biodiversity. Ecol. Bull., 46, 140-170. http://www.jstor. org/stable/20113213

Angradi, T.R., Schweiger, E.W., Bolgrien, D.W., Ismert, P. \& Selle T. (2004). Bank stabilization, riparian land use and the distribution of large woody debris in a regulated reach of the Upper Missouri River, North Dakota, USA. River Research and Applications, 20, 829-846. DOI: 10.1002/rra.797.

Buček, A. \& Lacina J. (1994). Biogeografické poměry. In Vybrané fyzickogeografické aspekty pro revitalizaci nivy Dyje v úseku VD Nové Mlýny - soutoks Moravou (pp. 46-98). Brno: Ústav geoniky AV ČR.

Buček, A. \& Lacina J. (2006). Biogeografická diferenciace v geobiocenologickém pojetí a její využití v krajinném plánování. In J. Dreslerová \& P. Packová (Eds.), Ekologie krajiny a krajinné plánování (pp. 18-29). Sborník ekologie krajiny 2. Kostelec nad Černými lesy: Lesnická práce.

Buček, A. \& Machar I. (2012). Application of landscape ecology in the assessment of anthropogenic impacts on the landscape: landscape-ecological aspects of the project "Danube-Oder-Elbe Canal“ in the territory of the Czech Republic. Olomouc: Univerzita Palackého.

Darby, S. \& Sear D. (2008). River restoration: Managing the Uncertainty in Restoring Physical Habitat. Chicester: John Willey and Sons.

Eiseltová, M. (Ed.) (1995). Restoration of Stream Ecosystem - an integrated catchment approach. Gloucester: IWRB Publishing.

Klimo, E. \& Hager H. (Eds.) (2001). The floodplain forests in Europe: current situation and perspectives. European Forest Institute Research Report, 10. Leiden: Koninklijke Brill NV.

Klimo, E., Hager, H., Matic, S., Anic, I. \& Kulhavý J. (Eds.) (2008). Floodplain forests of the temperate zone of Europe. Kostelec nad Černými lesy: Lesnická práce.

Koontz, T.M. \& Bodine J. (2008). Implementing ecosystem management in public agencie: Lessons from the US Bureau of Land Management and Forest Services. Conserv. Biol., 22, 60-69. DOI: 10.1111/j.15231739.2007.00860.x. 
Lambeck, R.J. (1997). Focal species: a multi-species umbrella for nature conservation. Conserv. Biol., 11, 849-856. DOI: 10.1046/j.1523-1739.1997.96319.x.

Mace, G.M. \& Baillie J.E.M. (2007). The biodiversity indicators: Challenges for science and policy. Conserv. Biol., 21, 1406-1413. DOI: 10.1111/j.1523-1739.2007.00830.x.

Machar, I. (2001). Ekologický nivní fenomén. In V. Petříček (Ed.), Sborník z konference Tvář naší země - krajina domova (pp. 135-137). Vol. I. Praha: Česká komora architektů.

Machar, I. (2008). Floodplain forest of Litovelské Pomoraví and their management. J. For. Sci., 54 (8), 355-369.

Machar, I. (2010). Use of the Concept of Umbrella Species in Landscape Ecology for the Environmental Impact Assessment of Investment Projects Implemented in the Landscape. Journal of Landscape Studies, 3, 13-27.

Machar, I. (2011). The impact of floodplain forest habitat conservation on the structure of bird breeding communities. Ekológia (Bratislava), 30(1), 36-50. DOI: 10.4149/ekol_2011_01_36.

Machar, I. \& Pechanec V. (2011). Application of geoecological concept of the alluvial landscape in the creation of nature reserve (case study from Czech Republic). Acta Universitatis Agriculturae et Silviculturae Mendelinae Brunensis, 16(3), 123-134.

Machar, I. (2012a). Obnova říční krajiny na Olomoucku. In L. Drobilová (Ed.), Venkovská krajina (pp. 117-126). Sborník z medziárodnej konference. Brno: CZ IALE.

Machar, I. (2012b). The effect of floodplain forest fragmentation on the bird community. J. For. Sci., 58(5), $213-224$.

Malanson, G.P. (1993). Riparian landscapes. Cambridge: Cambridge University Press.

Mezera, A. (1956). Středoevropské nižinné luhy I. Praha: Československá akademie zemědělských věd.

Míchal, I., Buček, A., Hudec, K., Lacina, J., Macků, J. \& Šindelář J. (1992). Obnova ekologické stability lesů. Praha: Academia.

Olson, D.M. \& Dinerstein E. (1998). A representation approach to conserving the Earths most biologically valuable ecoregions. Conserv. Biol., 12, 502-515. DOI: 10.1046/j.1523-1739.1998.012003502.x.

Oszlányi, J. (1999). Consequences of anthropic impact on Danube floodplain forests in Slovakia. Ekológia (Bratislava), 18(Suppl. 1), 103-110.

Oszlányi, J. (2000). Forestry-managerial measurements in the context of landscape-ecological planning in the Danube river inundation. Ekológia (Bratislava), 19(Suppl. 2), 112-117.

Prach, K., Jeník, J. \& Large A. (Eds.), 1996. Floodplain ecology and management. Amsterdam: SPB Academic Publishing.

Pretel, J. (2009). Současný vývoj klimatu a jeho výhled. Ochrana Př́rody, 64(zvláštní číslo), 2-7. Roth, P. \& Plesník J. (2004). Biologická rozmanitost na Zemi: stav a perspektivy. Praha: Scientia.

Seják, J. \& Dejmal I. (Eds.)(2003). Hodnocení a oceňování biotopů České republiky. Praha: Český ekologický ústav.

Seják, J. \& Pokorný J. (2008). Oceňování ekosystémových služeb na př́ikladu říční nivy. In D. Pithart, Z. Benedová \& K. Křováková (Eds.), Ekosystémové služby řiční nivy (pp. 183-190).

Sborník př́íspěvků z konference. Třeboň: Ústav systémové biologie a ekologie AV ČR.

Starr, Ch. (2005). Woodland management. Ramsbury: Crowood Press.

Šindlar, M., Lohniský, J., Zapletal, J. \& Machar I. (2010). Wood debris in rivers - one of the key factors for management of the floodplain forest habitats of European importace. Journal of Landscape Ecology, 2(2), 56-72.

Trémoliéres, M. \& Schnitzler A. (Eds.) (2007). Floodplain Protection, Restoration, Management. Why and how. Paris: Lavoisier SAS.

Vlček, L. \& Šindlar M. (2002). Geomorfologické typy vodních toků a jejich využití pro revitalizace. Vodní Hospodárství, 52(6), 172-176.

Vacek, S. (2003). Minimum area of forest left to spontaneous development in protected areas. J. For. Sci., 49(8), 349-358.

Vašíček, F. (1985). Natural conditions of floodplain forests. In M. Penka, M. Vyskot, E. Klimo \& F. Vašíček (Eds.), Floodplain Forest Ecosystem I. Before Water Management Measurements (pp. 13-30). Praha: Academia. 